\title{
Comparative Analysis of Methodologies to Evaluate Air Cargo Carriers' Service Quality: Focusing on SERVQUAL and SERVPERF
}

\author{
Park, A Rima and Hun-Koo Hab
}

\begin{abstract}
With an increasing air cargo demand in the global air cargo transport industry, not only domestic airlines but also foreign carriers are actively investing in the air cargo service sector and trying to provide a differentiated service in order to gain a competitive advantage. There are a variety of service quality models available but most research to date has not found an optimal model for the air cargo service sector.

Using questionnaire data collected from air freight forwarders in Korea with respect to the air cargo service provided by Korean Air, Asiana Airlines, and foreign carriers(JAL or China Eastern), this paper compares four models in measuring the service quality in the air cargo sector and identifies the best model. We then analyze the weakness of each airline's service operation and make suggestions for improvement.

For demonstration analysis, the survey of domestic air cargo forwarders revealed that Reliability $>$ Responsiveness $>$ Supply ability $>$ Security in important order in air cargo service quality dimension. In the context of this paper, we considered four models unweighted SERVQUAL, unweighted SERVPERF, weighted SERVQUAL, and weighted SERVPERF - for our investigation into which is the most suitable model in the air cargo service sector with testing of goodness of fit by three criteria. Our results indicate that the most suitable model for the air cargo service sector is the weighted SERVPERF model.
\end{abstract}

Keywords : Service quality, air cargo, SERVQUAL, SERVPERF

\footnotetext{
a Graduate School of Logistics, Inha University

b Professor, Graduate School of Logistics, Inha University
} 


\section{Introduction}

Air cargo service has developed rapidly because of the containerization of air cargo, the increasing demand for high-value products, the requirement for speed, and so on. As a result, many airlines specializing in carrying cargo and air freight forwarders have been created by this situation. Air freight forwarding is where an indirect air carrier consolidates many small shipments into one large shipment and then offers the large shipment as one entity to the airlines, as well as performing an important role in organizing and managing the transportation of air cargo consignments. With increased air cargo demand, air freight forwarders have become significant transportation participants.

Due to the depression of the world economy and natural disasters, cargo demand has fallen since 2009. Nevertheless, the IATA announced that world air cargo traffic will increase constantly over the next 5 years from a long-term point of view. Actually, world air cargo traffic has grown at an annual rate of approximately 5.24 percent over the last ten years. Thus, increasing competition is forcing carriers to lower ticket prices or cargo charges. However, competition on the cost side is not desirable since most of the airlines cut off the price. For this reason, they have tried to improve their service quality to achieve a competitive advantage.

In this context, this paper has three main objectives. First, we will identify the decisive factors for air cargo service quality. Second, we will establish the service levels of airlines by using service quality measurements. Finally, we will determine the optimal measure of service quality in the air cargo sector by comparing unweighted SERVQUAL and SERVPERF, and weighted SERVQUAL and SERVPERF measures.

To sum up, we set out to examine air cargo service quality factors and airline's cargo service quality such as Korean air, Asiana air, JAL or china Eastern and analyze the best service quality evaluation model in airline's air cargo areas.

\section{Literature Review}

The concept of service quality is basically defined as a comparison of expectations with performance, as suggested by Parasurman et al.(1985) who developed the first SERVQUAL model. The SERVQUAL model is a questionnaire designed to measure the gap between the expectations and perceptions of a customer in a particular service sector. This questionnaire has five categories: Tangible, Reliability, Responsiveness, Assurance, and Empathy (Parsuraman et al. 1988.1991a). 
The former studies focus mainly on the airline passenger service sector. Of the five SERVQUAL dimensions, most researchers have found the most important factors to be reliability, tangible, and empathy (Cheon-Woo Park, 2003; Mohammad Mehdi, 2007). Some researchers revised the basic SERVQUAL dimensions to fit the air cargo service industry. In accordance with Gye-Sup Kim et al. (2004), passengers recognized baggage claim processing time as the most important service factor in the passenger sector. Also, Shiang-Min Meng et al. (2010) defined the construct of service criteria of air cargo logistics providers.

Similarly, there is also a way to evaluate the air cargo service area. Byoung Kwon Choi (2007) used the SERVQUAL scale to investigate the factors which determine airport service quality and the differentiation of perceptions of airport service quality between airport users, namely Korean freight forwarders, 3PL, entities, integrators and the airport authority. There are notable differences in the cognition of airport service quality between the airport authority's perception and that of the airport customer, as well as that between the airport customer's perception and expectation.

Although the SERVQUAL model is generalized in evaluating service quality, Cronin and Taylor (1992) conclude that current performance best reflects a customer's perception of service quality and that expectations are not part of this concept. In addition, they prefer to recommend the unweighted SERVPERF model for measuring service quality, as it has higher predictive validity of customers' satisfaction by comparing four models: unweighted SERVQUAL and SERVPERF models; and weighted SERVQUAL and SERVPERF models (Cronin et al., 1992, Babakus et al., 1992). In line with this approach, Sabri T. Erdil et al. (2011) usefully provided information about the differences between the two different service quality scales with their findings when applied to the Turkish airline industry by comparing unweighted and weighted SERVQUAL and SERVPERF models. According to exploratory factor analysis and correlation coefficients, the weighted SERVPERF model explains perceived service quality much better than the weighted SERVQUAL model. In other words, the weighted SERVPERF model appears to be superior to the weighted SERVQUAL model. In addition, comparative analyses have been made to find the most suitable model in other service industries, such as banks and hospitals.

More recently, a number of studies have estimated service quality in the air cargo service sector using other service evaluation methods or have combined various methods of analysis, such as Analytical Hierarchy Process (AHP), fuzzy theory, and Quality Function Deployment (QFD), with the SERVQUAL or SERVPERF models. The work of Chi-Eun $\mathrm{Na}$ (2009), for example, investigated service quality competitiveness in the cargo operations of Korean Air, and applied methodologies including the expert question survey, AHP, and fuzzy integral. Consequently, the most important service quality was infra, and 
the reliability in air cargo service. Analyzing customer requirements is critical in the service industry. For this reason, Rong-Tsu Wang (2007) adopted quality function deployment in order to evaluate the service quality levels and suggest performance improvements in the air cargo service of China Airlines. Yonghwa Park et al. (2009) examined the relative importance of factors that influence the adoption of air express delivery services, such as promptness, accuracy, safety, information, convenience, economic efficiency, and dependability. Accuracy and promptness were found to be the most influential service factors. In addition, they evaluated the competitiveness of air cargo express carriers in the Korean market by using AHP analysis, targeting DHL, UPS, EMS, FedEX and TNT. The results revealed that DHL is the most competitive provider of its kind in the Korean market.

\section{Research Methodology}

\subsection{Questionnaire Design}

Researchers studying the air cargo service industry have suggested a wide range of air cargo service quality factors and dimensions. However, there are a number of common service factors in the air cargo service area. Therefore, this research extracted those elements suggested in the literature review with which to measure the service quality of air cargo. After all elements are total 27 extracted, the element where there is the redundancy is removed. To choose a evaluation components, final factors defined through the expert survey which conducted from respondents represent related to air cargo expert by using e-mail between 1 and 10 July 2012. An elements were identified which chosen more than half of participants. 17 valuable responses excluding 3 useless samples were gathered. As a result, the representative evaluation components extracted total 14 factors.

Service quality is evaluated using a SERVQUAL model comprising five dimensions: Tangible, Reliability, Responsiveness, Assurance, and Empathy (PZE, 1988). However, this research defined four dimensions in the air cargo sector based on the literature review and expert opinions. Table 3-1 and Table 3-2 indicate the 4 service dimensions and 14 service components in the air cargo area. 
Table 3-1.

14 service components in the air cargo service sector

\begin{tabular}{|c|l|}
\hline Variables & \multicolumn{1}{|c|}{ Air cargo service quality factors } \\
\hline X1 & Securement of air cargo equipment and facility \\
\hline X2 & Processing ability of special cargo \\
\hline X3 & Developed information system \\
\hline X4 & Connection with other transportation \\
\hline X5 & Range of transport service area (Airline's route network) \\
\hline X6 & Coverage and policies when cargo was damaged \\
\hline X7 & Securement of safety related to transaction \\
\hline X8 & Regular flight schedule \\
\hline X9 & Quick dispatch about claims (Contract violation, etc.) \\
\hline X10 & Prompt securement of space (Afford to accept to urgent cargo) \\
\hline X11 & Prompt work process \\
\hline X12 & Check and control of cargo's safety \\
\hline X13 & Facility for enhancing security and safety \\
\hline X14 & Technology for enhancing security (RFID, etc.) \\
\hline
\end{tabular}

Table 3-2.

Definition of the 4 dimensions for air cargo service

\begin{tabular}{|c|l|}
\hline Dimensions & \multicolumn{1}{c|}{ Definition } \\
\hline Supply ability & Physical services and the operational ability to provide air cargo services \\
\hline Reliability & Ability to perform the promised service dependably and accurately \\
\hline Responsiveness & Willingness to help customers and provide prompt service \\
\hline Security and Safety & $\begin{array}{l}\text { Ability to protect from illegal interference and information of customer's } \\
\text { transactions and goods }\end{array}$ \\
\hline
\end{tabular}

Basically, if customers want to be provided with a high quality service from airlines, the airlines should consider their costs. Therefore, we assume that air freight forwarders willingness to pay for service with airlines for high air cargo service. It means that the questionnaires were composed based on this assumption. 


\subsection{Sample and Data Collection}

For this paper, the survey samples that were collected from respondents representing air cargo forwarders in Korea which using every three types of airline's air cargo service (Korean air, Asiana air, foreign airlines). In order to improve the response rate, responses indicating use of only one or two airlines were excluded as unuseful samples. Of the 170 questionnaires commissioned either by e-mail or face-to-face, 159 useful responses were collected. $54.08 \%$ of the respondents had more than 5 years work experience, while $72.96 \%$ of the firms identified themselves as having total sales of less than 50 billion Korean Won. Also, more than half of the exporting areas primarily were Asia area for air cargo service. In terms of the airlines used, a total of 53 samples were collected for each airline. The 159 samples were processed using the SPSS 18.0 statistics program.

\subsection{Measure and Index of Comparison}

The questionnaires designed the respondent's expectations, perceptions for each airlines and importance weights of four service quality dimensions using a constant sum type question which able to express the relative importance. Based on 14 service factors and 4 air cargo service dimensions, all the scale items were composed on a 5-point Likert scale ranging from 5 for strongly agree to 1 for strongly disagree.

In order to find the proper model for the air cargo area, we defined the three fitness criteria for this purpose. According to preceding reviews, there were comparative analysis between SERVQUAL and SERVPERF models. Most researchers compared between SERVQUAL and SERVPERF models in various service industry area for which model is the superior by comparing mainly 3 criteria. The first criteria is 'Total explained variance' which is the proportion of total variance in all the variables which is accounted for by that factor for testing. Second, in terms of the average reliability coefficient, we used Cronbach's alpha, which is a coefficient of internal consistency. It is commonly used as a measure of the reliability for a sample of examines, specifically whether several items that propose to measure the same general construct produce similar scores. Third, most previous research assumes that each of the service quality instruments have a relationship with a customer's satisfaction. Accordingly, this study tried to test between each service quality models and overall customer satisfaction by using multiple regression. After using multiple regression, we will judge by R-square coefficient. If it is higher, it means that the service quality model explains customer satisfaction more precisely than the other models. 


\section{Findings and Implications}

This section will provide the statistical data analysis using Exploratory Factor Analysis (EFA) and multiple regression analysis for the comparative study between the SERVQUAL and SERVPERF scales which whether considered weighted. There were mainly two approach analysis ; Exploratory Factor analysis (EFA), Multiple regression analysis.

\subsection{Reliability and Validity of the Instruments}

Exploratory Factor Analysis (EFA) is a useful statistical technique for verifying the reliability and validation of a survey and identifying the possible underlying factor structure of a set of observed variables (Child, 1990). Performing EFA to test the validity of each model, 14 times were tested using principle components analysis with varimax rotation. Table 4-1 shows that 4 models identified 4 dimensions according to eigen value are higher than the criteria value 1 and each factor loading are larger than the criteria 0.5 (Appendix A). In terms of the reliability of the dimensions, each dimension was higher than the cut-off criteria 0.5 (Appendix A). Thus, there were no deleted variables in the 4 models. The Kaiser-Meyer-Olkin (KMO) which show the adequacy of sampling and the results indicate an index more than 0.7 would imply a reasonable sign of adequacy for factor analysis. As Table 4-1 indicates, the KMO values of the 4 models were higher than 0.7 , which means that it acceptable for performing the factor analysis.

\section{Table 4-1.}

Summary of results of factor analysis

\begin{tabular}{|c|c|c|c|c|c|}
\hline Model & $\begin{array}{c}\text { Number of } \\
\text { factors }\end{array}$ & $\begin{array}{c}\text { Number of } \\
\text { variables }\end{array}$ & $\begin{array}{c}\text { Accumulated } \\
\text { variance } \%\end{array}$ & $\begin{array}{c}\text { Cronbach's } \\
\text { Alpha }\end{array}$ & $\begin{array}{c}\text { KMO/ } \\
\text { Bartlett }\end{array}$ \\
\hline $\begin{array}{c}\text { Unweighted } \\
\text { SERVQUAL }\end{array}$ & 4 & 14 & 65.99 & 0.78 & 0.836 \\
\hline $\begin{array}{c}\text { Unweighted } \\
\text { SERVPERF }\end{array}$ & 4 & 14 & 77.88 & 0.83 & $\begin{array}{c}993.411 \\
(\mathrm{p}=0)\end{array}$ \\
\hline $\begin{array}{c}\text { Weighted } \\
\text { SERVQUAL }\end{array}$ & 4 & 14 & 68.68 & 0.80 & $\begin{array}{c}1578.525 \\
(\mathrm{p}=0)\end{array}$ \\
\hline $\begin{array}{c}\text { Weighted } \\
\text { SERVPERF }\end{array}$ & 4 & 14 & 87.86 & 0.93 & $\begin{array}{c}951.781 \\
(\mathrm{p}=0)\end{array}$ \\
\hline
\end{tabular}


With regard to total explained variance from factor analysis, the unweighted SERVQUAL total variance of four factors account for $65.99 \%$ explaining the 14 items. While the unweighted SERVPERF model has had the rates of explained variance of $77.88 \%$ for four dimensions. Furthermore, when considering weighted, the weighted SERVQUAL total explained variance is $68.68 \%$ higher than the unweighted SERVQUAL model. However, the weighted SERVPERF model has the highest total explained variance compared other models. Therefore, this model have explained much more 14 items and 4 dimensions for air cargo service quality.

In addition, the 4 models which were considered in this paper were tested for internal consistency by using Cronbach's alpha. Commonly, if Cronbach's alpha value require a reliability of 0.70 or higher than this criteria to be an acceptable reliability coefficient. As Table 4-1 reveals, the 4 models can be considered quite reliable, while the weighted SERVPERF model clearly has the highest reliability compared to the other models.

\subsection{Relationship between Overall Customer Satisfaction and Air Cargo Service Quality of Each Model}

In line with earlier studies of comparative research between SERVQUAL and SPERVERF scale in other service industries, J. Joseph Cronin et al. (1992), Yang et al. (2002), and Oh et al. (2011) assumed that service quality is related to overall customer satisfaction. Therefore, in order to test the relationship, using factor scores from EFA and gaining overall customer satisfaction based on the questionnaire both were measured by multiple regression analysis. The dependent variables defined overall customer satisfaction and the independent variables were all dimensions of each of the models.

The results show that service quality is significantly related to overall customer satisfaction (see Table 4-2 and Appendix A) in the view of t-value and F-value, From Table 4-2, it explained that at $\mathrm{p}>0.05$ level, all dimensions of each models had a significantly positive relationship between service quality and user satisfaction ( $p$-value $=0.000$ or 0.001 ). 


\section{Table 4-2.}

Summary of results for the relationship between overall customer satisfaction and air cargo service quality of each model

\begin{tabular}{|c|c|c|c|c|c|}
\hline Model & $\begin{array}{c}\text { Dependant } \\
\text { variable }\end{array}$ & $\begin{array}{l}\text { Independent } \\
\text { variable }\end{array}$ & F-value & $\mathrm{P}>|\mathrm{F}|$ & R-squared \\
\hline $\begin{array}{l}\text { Unweighted } \\
\text { SERVQUAL }\end{array}$ & \multirow{4}{*}{$\begin{array}{c}\text { Overall } \\
\text { customer } \\
\text { satisfaction }\end{array}$} & Supply ability & 30.98 & 0.000 & 0.44 \\
\hline $\begin{array}{l}\text { Unweighted } \\
\text { SERVPERF }\end{array}$ & & Reliability & 59.32 & 0.000 & 0.60 \\
\hline $\begin{array}{c}\text { Weighted } \\
\text { SERVQUAL }\end{array}$ & & Responsiveness & 26.60 & 0.000 & 0.40 \\
\hline $\begin{array}{l}\text { Weighted } \\
\text { SERVPERF }\end{array}$ & & Security & 58.72 & 0.000 & 0.60 \\
\hline
\end{tabular}

\section{Appendix A. Exploratory Factor analysis Results}

\begin{tabular}{|c|c|c|c|c|c|c|c|c|c|}
\hline \multicolumn{10}{|c|}{ Unweighted SERVQUAL } \\
\hline \multirow[b]{2}{*}{ Dimension } & \multirow[b]{2}{*}{ variable } & \multicolumn{8}{|c|}{ Result } \\
\hline & & \multicolumn{4}{|c|}{ Factor Loading } & Eigen & $\begin{array}{l}\text { Portion } \\
\text { of }\end{array}$ & Accumulated & Alpha \\
\hline \multirow{3}{*}{ Reliability } & $\mathrm{X} 7$ & 0.829 & 0.234 & 0.111 & 0.167 & \multirow{3}{*}{2.524} & \multirow{3}{*}{18.03} & \multirow{3}{*}{18.03} & \multirow{3}{*}{0.86} \\
\hline & $\mathrm{X} 6$ & 0.79 & 0.176 & 0.181 & 0.197 & & & & \\
\hline & X9 & 0.762 & 0.217 & 0.29 & 0.215 & & & & \\
\hline \multirow{4}{*}{ Supply ability } & $\mathrm{X} 1$ & 0.281 & 0.746 & 0.232 & 0.034 & \multirow{4}{*}{2.311} & \multirow{4}{*}{16.51} & \multirow{4}{*}{34.54} & \multirow{4}{*}{0.754} \\
\hline & $\mathrm{X} 3$ & 0.15 & 0.675 & 0.317 & 0.17 & & & & \\
\hline & $\mathrm{X} 5$ & 0.079 & 0.662 & -0.032 & 0.208 & & & & \\
\hline & $\mathrm{X} 2$ & 0.371 & 0.649 & 0.155 & 0.265 & & & & \\
\hline \multirow{3}{*}{ Security } & $\mathrm{X} 14$ & 0.126 & 0.015 & 0.81 & 0.29 & \multirow{3}{*}{2.262} & \multirow{3}{*}{16.157} & \multirow{3}{*}{50.697} & \multirow{3}{*}{0.77} \\
\hline & $\mathrm{X} 13$ & 0.241 & 0.194 & 0.779 & 0.171 & & & & \\
\hline & $\mathrm{X} 12$ & 0.169 & 0.237 & 0.708 & 0.016 & & & & \\
\hline \multirow{4}{*}{ Responsiveness } & $\mathrm{X} 10$ & 0.237 & 0.09 & 0.021 & 0.813 & \multirow{4}{*}{2.141} & \multirow{4}{*}{15.291} & \multirow{4}{*}{65.987} & \multirow{4}{*}{0.723} \\
\hline & X11 & 0.33 & 0.224 & 0.164 & 0.639 & & & & \\
\hline & $\mathrm{X} 4$ & -0.197 & 0.355 & 0.321 & 0.596 & & & & \\
\hline & X8 & 0.283 & 0.172 & 0.24 & 0.587 & & & & \\
\hline
\end{tabular}




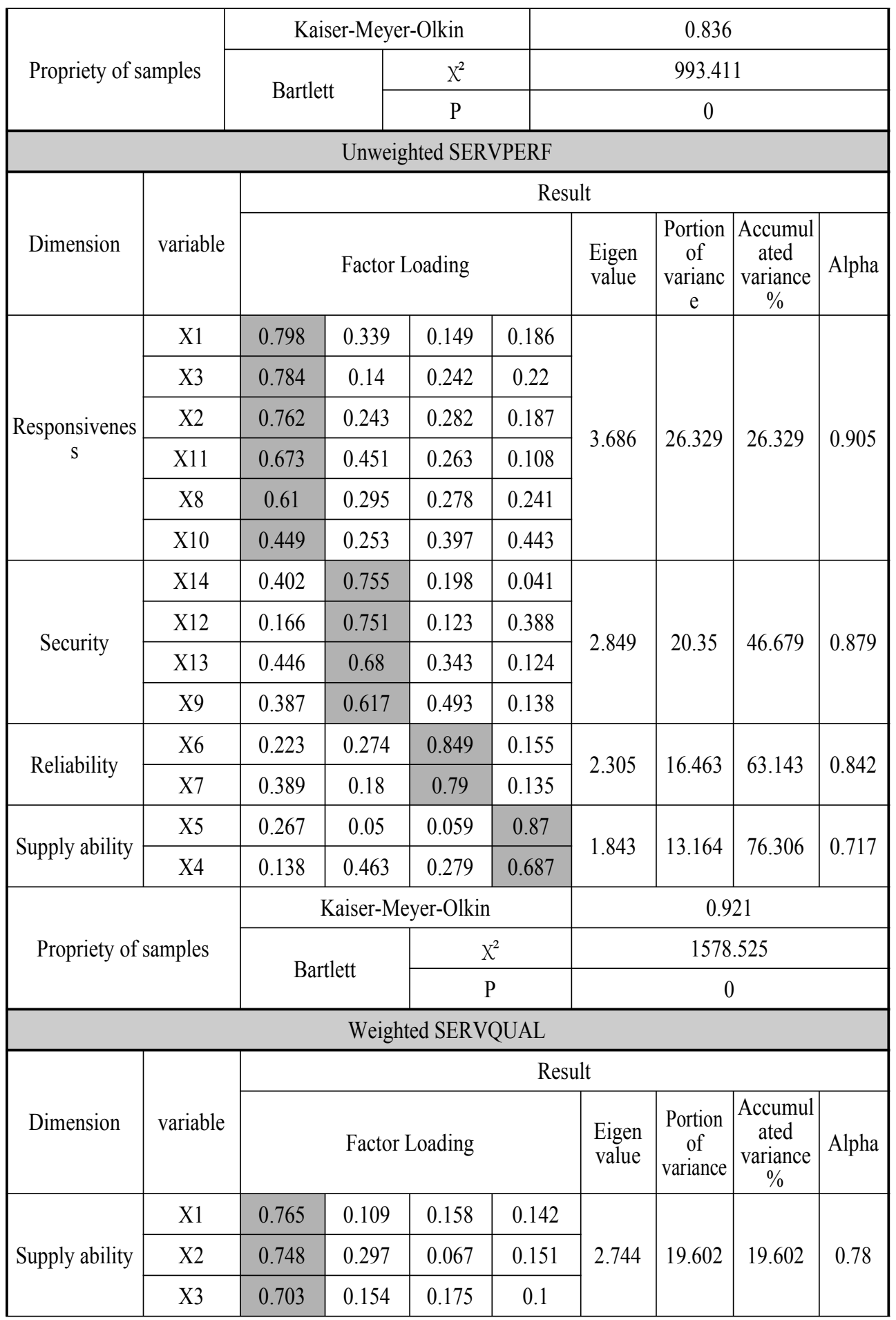




\begin{tabular}{|c|c|c|c|c|c|c|c|c|c|}
\hline & $\mathrm{X} 4$ & 0.661 & -0.005 & 0.084 & 0.138 & & & & \\
\hline & $\mathrm{X} 5$ & 0.659 & 0.043 & 0.019 & 0.034 & & & & \\
\hline \multirow{3}{*}{ Reliability } & $\mathrm{X} 7$ & 0.126 & 0.896 & 0.101 & 0.109 & \multirow{3}{*}{2.361} & \multirow{3}{*}{16.867} & \multirow{3}{*}{36.469} & \multirow{3}{*}{0.823} \\
\hline & $\mathrm{X} 6$ & 0.082 & 0.891 & 0.146 & 0.073 & & & & \\
\hline & $\mathrm{X} 8$ & 0.254 & 0.5 & 0.166 & 0.292 & & & & \\
\hline \multirow{3}{*}{ Security } & $\mathrm{X} 14$ & 0.052 & 0.171 & 0.839 & 0.111 & \multirow{3}{*}{2.286} & \multirow{3}{*}{16.325} & \multirow{3}{*}{52.795} & \multirow{3}{*}{0.823} \\
\hline & $\mathrm{X} 13$ & 0.16 & 0.265 & 0.832 & 0.065 & & & & \\
\hline & $\mathrm{X} 12$ & 0.18 & 0.01 & 0.823 & 0.07 & & & & \\
\hline \multirow{3}{*}{$\begin{array}{c}\text { Responsivenes } \\
\mathrm{S}\end{array}$} & $\mathrm{X} 10$ & 0.131 & 0.116 & -0.004 & 0.851 & \multirow{3}{*}{1.88} & \multirow{3}{*}{13.429} & \multirow{3}{*}{66.224} & \multirow{3}{*}{0.745} \\
\hline & $\mathrm{X} 11$ & 0.207 & 0.147 & 0.156 & 0.832 & & & & \\
\hline & X9 & 0.164 & 0.515 & 0.248 & 0.515 & & & & \\
\hline \multirow{3}{*}{\multicolumn{2}{|c|}{ Propriety of samples }} & \multicolumn{4}{|c|}{ Kaiser-Meyer-Olkin } & \multicolumn{4}{|c|}{0.781} \\
\hline & & \multirow{2}{*}{\multicolumn{2}{|c|}{ Bartlett }} & \multicolumn{2}{|c|}{$x^{2}$} & \multicolumn{4}{|c|}{951.499} \\
\hline & & & & \multicolumn{2}{|c|}{$\mathrm{P}$} & \multicolumn{4}{|c|}{0} \\
\hline \multicolumn{10}{|c|}{ Weighted SERVPERF } \\
\hline \multirow[b]{2}{*}{ Dimension } & \multirow[b]{2}{*}{ variable } & \multicolumn{8}{|c|}{ Result } \\
\hline & & & Factor & oading & & $\begin{array}{l}\text { Eigen } \\
\text { value }\end{array}$ & $\begin{array}{l}\text { Portion } \\
\text { of } \\
\text { varianc } \\
\text { e }\end{array}$ & $\begin{array}{c}\text { Accumul } \\
\text { ated } \\
\text { variance } \\
\% \\
\%\end{array}$ & Alpha \\
\hline & $\mathrm{X} 1$ & 0.964 & -0.018 & 0.032 & 0.025 & \multirow{5}{*}{4.377} & & & \\
\hline & $\mathrm{X} 2$ & 0.952 & -0.006 & 0.037 & 0.021 & & & & \\
\hline Supply ability & $\mathrm{X} 3$ & 0.945 & 0.001 & 0.003 & 0.079 & & 31.265 & 31.265 & 0.963 \\
\hline & $\mathrm{X} 5$ & 0.907 & -0.069 & -0.032 & -0.031 & & & & \\
\hline & $\mathrm{X} 4$ & 0.902 & 0.123 & 0.039 & 0.031 & & & & \\
\hline & $\mathrm{X} 13$ & -0.019 & 0.964 & -0.088 & 0.022 & & & & \\
\hline Security & $\mathrm{X} 12$ & 0.014 & 0.963 & -0.074 & -0.031 & 2.815 & 20.109 & 51.374 & 0.87 \\
\hline & $\mathrm{X} 14$ & 0.026 & 0.944 & -0.133 & -0.009 & & & & \\
\hline & X9 & 0.077 & -0.026 & 0.939 & 0.114 & & & & \\
\hline $\begin{array}{c}\text { Responsivenes } \\
\mathrm{s}\end{array}$ & $\mathrm{X} 11$ & -0.007 & -0.131 & 0.932 & 0.078 & 2.711 & 19.366 & 70.74 & 0.936 \\
\hline & $\mathrm{X} 10$ & -0.01 & -0.138 & 0.923 & 0.053 & & & & \\
\hline & $\mathrm{X} 7$ & -0.013 & -0.025 & 0.162 & 0.911 & & & & \\
\hline Reliability & $\mathrm{X} 6$ & 0.04 & 0.074 & 0.192 & 0.878 & 2.397 & 17.12 & 87.861 & 0.96 \\
\hline & $\mathrm{X} 8$ & 0.061 & -0.062 & -0.097 & 0.874 & & & & \\
\hline
\end{tabular}




\begin{tabular}{|c|c|c|c|}
\hline \multirow{2}{*}{ Propriety of samples } & \multicolumn{2}{|c|}{ Kaiser-Meyer-Olkin } & 0.787 \\
\cline { 2 - 4 } & \multirow{2}{*}{ Bartlett } & $\mathrm{X}^{2}$ & 2462.034 \\
\cline { 3 - 4 } & & $\mathrm{P}$ & 0 \\
\hline
\end{tabular}

In terms of the of the unweighted SERVPERF and weighted SERVPERF models were approximately what was statistically significant. Basically value is the proportion of that variance is accounted. With compared to SERVQUAL models, SERVPERF models have much more explained than SERVQUAL models. The R-squared values of unweighted and weighted SERVQUAL models were roughly 0.44. The unweighted SERVQUAL model had the lowest r-squared value. As a result, it proves that SERVPERF models are better than SERVQUAL models in the air cargo service sector when considering customer satisfaction.

\subsection{Testing of Fitness to Find the Best Service Quality Evaluation Model in the Air Cargo Sector}

In terms of finding the best service quality evaluation model, considering comprehensive 3 main criteria, it is clear that the weighted SERVPERF scale provides the highest service quality model in the air cargo service sector. As such, it is possible to say that air cargo service can be more precisely assessed using a weighted SERVPERF model than by using the other scales.

\section{Table 4-3.}

The result of testing fitness of each model

\begin{tabular}{|c|c|c|}
\hline Model & Model Fitness Criteria & Result \\
\hline \multirow{3}{*}{ Unweighted SERVQUAL } & Total explained variance & 65.99 \\
\cline { 2 - 3 } & Cronbach's alpha & 0.78 \\
\cline { 2 - 3 } & R-squared & 0.44 \\
\hline \multirow{3}{*}{ Unweighted SERVPERF } & Total explained variance & 77.88 \\
\cline { 2 - 3 } & Cronbach's alpha & 0.83 \\
\cline { 2 - 3 } & R-squared & 0.60 \\
\hline \multirow{3}{*}{ Weighted SERVQUAL } & Total explained variance & 68.68 \\
\cline { 2 - 3 } & Cronbach's alpha & 0.80 \\
\cline { 2 - 3 } & R-squared & 0.40 \\
\hline \multirow{3}{*}{ Weighted SERVPERF } & Total explained variance & 87.86 \\
\cline { 2 - 3 } & Cronbach's alpha & 0.93 \\
\cline { 2 - 3 } & R-squared & 0.60 \\
\hline
\end{tabular}




\subsection{Implications}

The results of this research have the following implications and suggest the following improvements. Firstly, it is in the interests of air cargo forwarders to pay greater attention to their 'Security and Safety' services than perhaps they do now. In short, airlines are recommended to pursue service strategies which focus on their customers. We tested the relationship between overall satisfaction and service quality, and the results were shown to be statistically significant. This means that when airlines improve service quality, overall satisfaction levels will increase. For this reason, airlines should prioritize strategies which take into account the views of their customers.

Second, despite the arguments in favor of the service quality measurement model, the best model was found to be the weighted SERVPERF model. In addition, it is meaningful to analyze the importance weights of four air cargo service dimension. Thus, this result can figure out the service level more precisely in air cargo service sector in future study.

Third, air cargo forwarders highlight reliability as the most important aspect of service. Therefore, airlines should concentrate on reliability and responsiveness within the context of their long-term and differentiated strategies.

Finally, we evaluated the service quality of Northeast Asia's representative airlines within the context of the fierce competition to become the main hub airport in Northeast Asia. Currently, Korean air cargo forwarders consider Korean Air to have the highest service quality among the airlines compared. In order to be competitive, most airlines need to improve their reliability and implement long-term service strategies for their customers.

\section{Concluding Remarks}

At a time when the airline industry is facing a variety of obstacles, such as the continuing economic crisis, increasing fuel costs, natural disasters, and so on, the air cargo sector has become more important at a time when airlines are trying to improve their service quality in order to be competitive rather than reducing prices. Service quality decided by service user's perception and developed the service quality tools for evaluation of service level. The aim of this paper was to identify the air cargo service quality factors and conduct a comparative analysis using 4 service quality models in order to evaluate the service quality provided by Korean Air, Asiana Airlines, and foreign airlines.

First, 14 service elements were identified based on a survey of experts and previous research in this area, together with the 4 service quality dimensions - supply ability, 
reliability, responsiveness, security and safety - taken from the literature review and the opinions of the experts. It is interesting that air cargo security was identified as the most critical factor in the air cargo sector.

Second, the 4 models were analyzed comparatively to find the best model in the air cargo area. there were 3 main criteria which were total explained variance, the average of Cronbach's alpha coefficient, R-squared from regression between the overall customer satisfaction and service quality dimensions. By comparing the criteria among the 4 models, the weighted SERVPERF model was found to have the highest values. These results suggest that when evaluating the air cargo service, the weighted SERVPERF model is the most reliable of the models available. In addition, the survey time can be reduced and measurement errors minimized because it is not considered the expectation part.

In the course of this research, we utilized 14 service quality components based on the literature review and an expert survey. Recently, a lot of new service quality factors have been identified due to the high interest in the service sector. However, it is difficult to consider many factors according to the recent trends. Therefore, it would be interesting to consider environmental factors. For example, the following question related to environmental service was included as an item on the questionnaire: "The air industry is beginning to consider environmental issues. If airlines provided an environmental air cargo service utilizing paperless or standardized packing, would you be willing to contribute to the airlines' costs?". Table 5-1 shows the survey results of the respondents' willingness to pay for such an environmental service.

\section{Table 5-1.}

Survey results of willingness to pay for environmental service

(Unit: Persons)

\begin{tabular}{|l|l|}
\hline I'm willing to pay with airline & $80(50.32 \%)$ \\
\hline I don't want to pay together because cost will increase & $46(28.93 \%)$ \\
\hline Other & $33(20.75 \%)$ \\
\hline
\end{tabular}

The second disadvantage of this paper was that the survey target defined only domestic air cargo forwarders. As a result, we cannot say that these research results are representative of air cargo service quality. It is suggested that a more extensive study is made of Northeast Asian air freight forwarders so that it is possible to compare the importance of service quality between each of the countries in the region.

Finally, this study was limited by the decision to adopt only 3 main criteria to find the best model for the air cargo service. Further studies should be undertaken in order to establish the best service quality evaluation model based on a wider range of model fitness criteria. 


\section{References}

Babakus,E. and G.W.Boller(1992), "An Empirical Assessment of the SERVQUAL Scale", Journal of Business Research, Vol.2, pp.253-68.

Bolton, Ruth N. and James H. Drew(1991), "A Multistage Model of Customers' Assessments of Service Quality and Value", Journal of consumer Research, Vol.17, pp.375-384.

Oh, Seonil and Gyungsik Kang(2011), "Comparison of SERVQUAL and SERVPERF model in Measuring Service Quality of Pallet Pool", Journal of Korea Society of Safety Management Science, Vol.13 No.2, pp.157-167.

Choi, Byung-gwon(2007), "Study on the perceived Service Quality of Incheon International Airport's Cargo Transport Service User", Journal of Korea Society of Trade and Commerce, Vol.33, pp.167-190.

Chou, Chien-Chang, Li-Jen L., Sue-Fen H., Jeng-Ming Y., and Tzeu-Chen H.(2011), “An evaluation of airline service quality using the fuzzy weighted SERVQUAL method", Applied Soft Computing, Vol.11, pp. 2117-.2128

Cronin, J. Joseph, Jr. and S.Taylor(1992), "Measuring Service Quality : A Reexamination and Extension", Journal of Marketing, Vol.58, pp.55-68.

Jang, Dae-sung(2003), "Comparative Study on Measurement Methods of Airline Service Quality", Journal of Quality Management Society, Vol. 31, No.4, pp.36-54

Kim, Gyesup and Jooeun Cho (2004), "The Importance of Airline Company's Service Quality: Relationship between Satisfaction and Performance", Tourism Research, Vol.19 No.2, pp.35-61.

Kwon, Jaehyun, Hyojung Kim and Kiwhan Kim (2010), “Allowable Range of Customer's Expectations on Airline Service", Journal of the Aviation Management Society of Korea, Vol.8 No.3, pp.131-147 
Lee, Dooyoung and Hee-jeon Kim (2003) , "A Study on Evaluation of University Library Service Quality with SERVQUAL and SERVPERF", Journal of Korea Society of Information Management, pp. 73-92.

Lewlyn, L.R. Rodrigues and Gopalakrishna B.,K.V.M.Varambally, Farahnaz G.M.(2011), "Comparison of SERVQUAL and SERVPERF metrics : an empirical study", The TQM Journal, Vol. 23 No. 6, pp. 629-643

Mohammad Mehdi Bozorgi(2007), "Measuring Service Quality in the Airline Using SERVQUAL Model (Case of IAA)", Master's thesis, Lulea University of Technology.

Moon Jiyeon and Hun-Koo Ha, (2009), "Factors to Choose Aviation Companies of Air Freight Forwarders: Application of AHP", KOREA LOGISTICS REVIEW, Vol.19, No.2, pp.237-253.

Parasuraman, A., L.L. Berry, and V.A. Zeithaml(1985), "A Conceptual Model of Service Quality and Its Implication for Future Research," Journal of Marketing, Vol49, pp41-50.

Parasuraman, A., L.L. Berry, and V.A. Zeithaml (1991), "Refinement and Reassessment of the SERVQUAL Scale," Journal of Retailing, Vol.67, pp.420-450.

Parasuraman, A., L.L. Berry, and V.A. Zeithaml(1994b), "Reassessment of Expectations as a Comparison Standard in Measuring Service Qulity : Implications for Future Research", Journal of Marketing, Vol.58, pp.111-124.

Parasuraman, A., L.L. Berry, and V.A. Zeithaml(1994a), "Moving Forward in Service Quality Research : Measuring Different Levels of Customer Expectations, Comparing Alternative Scales, and Examining the Performance-Behavioral Intention Link", Marketing Science Institute Working Paper, Report No. pp.94-114.

Parasuraman, A., L.L. Berry, and V.A. Zeithaml(1998), "SERVQUAL : A Multiple-Item Scale for Measuring Consumer Perception of Service Quality", Journal of Marketing, Vol.64, No.1, Spring, pp.16-17. 
Park, Cheon-woo(2003), "A study on the Improvement of the Airline Service Quality", Culture and Tourism Research, Vol. 5 No. 1, pp.469-486.

Rong-Tsu Wang(2007), "Improving service quality using quality function deployment: The air cargo sector of China airlines", Journal of Air Transport Management, Vol.13, pp.221-228.

Sabri T.E., Oguz Y.(2011), "Measuring service quality and a comparative analysis in the passenger carriage of airline industry", Procedia Social and Behavioral Sciences, Vol.24, pp.1232-1242.

Shiang-Min M., Gin-Shuh L, Kuang L., Shiou-Yu C.(2010), "Criteria for services of air cargo logistics providers: How do they relate to client satisfaction?", Journal of Air Transport Management, Vol.16, pp.284-286.

Siobhan T., Dawna L., R., Blaise W.J.(2008), "Airline service quality : Exploratory analysis of consumer perceptions and operational performance in the USA and EU", Managing Service Quality, Vol. 18 No. 3.

Yonghwa Park, Jung Kyu Choi, Anming Zhang (2009), "Evaluating competitiveness of air cargo express services", Transportation Research Part E, Vol.45, pp.321-334

Zeithal V.A.,L.L.Berry, A.Parasuraman (1996), "The Behavioral consequences quality?", Journal of Marketing, Vol.60, No.2, pp.31-46. 